Judyta Krajewska ${ }^{1}$

\title{
Teoria pulsu w starożytności
}

„Lekarz nie może przepisać listem odpowiedniego czasu na jedzenie lub kąpiel; musi [najpierw] wyczuć puls"2

\section{Wstęp}

Współcześnie mierzenie pulsu jest jednym z podstawowych badań służących do oceny stanu naszego organizmu w momencie jego pomiaru i może stanowić podstawę do wykrycia zaburzeń rytmu serca, jak również innych stanów patologicznych ${ }^{3}$. Dla lekarza sprawdzającego tętno istotne

1 Dr Judyta Krajewska, doktor nauk humanistycznych w zakresie historii, nauczyciel akademicki na Wydziale Nauk Historycznych oraz Wydziale Medycznym Collegium Medicum Uniwersytetu Kardynała Stefana Wyszyńskiego w Warszawie, zainteresowania badawcze: historia medycyny, profilaktyka i promocja zdrowia, epidemie i epidemiologia; e-mail: j.iwanska@uksw.edu.pl; ORCID: 0000-0002-3070-1663

2 „Non potest medicus per epistulas cibi aut balinei tempus eligere vena tangeda est”. Por. Seneka, Ad Lucilium. Epistulae morales, t. 1, tł. R.M. Gummere, London 1917, s. 148.

3 Dlaczego badanie tętna, które faktycznie możemy przeprowadzić sami, jest tak istotne dla oceny naszego zdrowia? Przyśpieszone lub zwolnione tętno, poza tym, że jest spowodowane różnymi czynnikami sfery psychicznej i emocjonalnej, może sugerować niemiarową pracę serca, w tym różnego rodzaju arytmie groźne dla naszego życia. Przyspieszony puls może towarzyszyć różnego rodzaju stanom zapalnym toczącym się w naszym organizmie, w przebiegu których występuje gorączka, ale może być charakterystyczny dla innych schorzeń i anomalii naszego zdrowia. „Częstości tętna sprzyjają: różne stany emocjonalne, stres, nadmierne pobudzenie w trakcie nadczynności tarczycy, stany nerwicowe, choroby ośrodka wytwarzania tzw. bodźców dla skurczów przedsionków lub komór serca, wszelkiego rodzaju stany gorączkowe, różne spadki ci- 
są m.in. wyczuwalność pulsu, ilość uderzeń na minutę, odstępy między uderzeniami i ich nasilenie.

Pod pojęciem pulsu, czyli tętna rozumiemy rytmiczny ruch naczyń polegający na rozciąganiu i skurczu ich ścian na skutek mechanicznego działania tłoczonej przez serce krwi. Krew pulsuje zarówno w naczyniach tętniczych (tętnicach), jak i żylnych (żyłach) ${ }^{4}$. Puls w tętnicach jest efektem zgodnego z kierunkiem przepływu krwi i przewodzenia akcji serca wzdłuż ścian naczyń od serca na obwód, w żyłach natomiast przeciwnie do kierunku przepływu krwi.

Kto i kiedy odkrył diagnostyczne znaczenie tętna? Czy na podstawie dostępnych nauce materiałów źródłowych potrafimy ustalić, kiedy w historii medycyny zaczyna się zainteresowanie pulsem jako formą przedmiotowego i fizykalnego badania pacjenta?

\section{Badania nad pulsem w starożytnych kulturach Wschodu}

Prawdopodobnie jednym $\mathrm{z}$ najstarszych zachowanych akadyjskich dzieł jest Epos o Gilgameszu, treść którego była formowana przez pięć niezależnych sumeryjskich poematów o Gilgameszu, legendarnym sumeryjskim władcy akadyjskiego miasta Uruk. Poematy te, prawdopodobnie kopie utworów z końca III tysiąclecia przed Chrystusem, zostały spisane na tabliczkach datowanych na I połowę drugiego tysiąclecia przed Chrystusem ${ }^{5}$. Najdłuższa, być może skompilowana wersja eposu z XIII wieku przed Chrystusem, nazywana standardową, zawiera opis lamentu Gilgamesza po śmierci przyjaciela (tabliczka VIII) ${ }^{6}$ : „Dotykam go, ale zmarły nie wstaje.

śnienia tętniczego krwi (niewydolność krążenia, krwotok, przedawkowanie preparatów obniżających ciśnienie krwi, biegunki) - jako próba adaptacji krążenia, niewydolność układu oddechowego (rozedma, dychawica oskrzelowa, zapalenia, zakrzepy i zatory w krążeniu płucnym oraz powstałe w ich następstwie zawały płuca, ropnie bądź zwłóknienia pozapalne płuc, różnego rodzaju pylice i nowotwory płuc) - jako konsekwencją niedotlenienia krwi i próby wyrównywania niedoborów przy pomocy przyspieszenia przepływu krwi, wszelkiego rodzaju niedokrwistości - jako konsekwencja niedostatecznego transportu tlenu do tkanek z powodu małej liczy erytrocytów, picie dużej ilości alkoholu, picie dużej ilości kawy, nałogowe palenie papierosów" (K. Janicki, Domowy Poradnik Medyczny, Warszawa 2003, s. 56-57).

4 Tętnienie w naczyniach żylnych jest jednak znacząco słabsze, co sprawia, że jego pomiar jest rzadziej wykorzystywany diagnostycznie.

5 K. Szarzyńska, Eposy sumeryjskie, Warszawa 2003, s. 53.

6 M. Kovacs, The Epic of Gilgamesh, Stanford 1989, s. 21. 
Dotykam jego serca, ale wcale nie bije"'. Wypowiedziane przez władcę Uruk zdanie może sugerować, że Akadyjczycy utożsamiali śmierć z ustaniem akcji serca i wyczuwaniem pulsu. Czy znajomość konsekwencji ustania „bicia” była tożsama z wiedzą o znaczeniu pomiaru pulsu u żyjącego chorego? Zbyt mało odczytanych mezopotamskich tekstów źródłowych nie pozwala na takie stwierdzenie, tym bardziej, że badania pośmiertne w starożytnej Mezopotamii nie były wykonywane. Sekcje wykonywano przede wszystkim dla celów wróżbiarskich i były ograniczone do autopsji wątroby i płuc zdrowych zwierząt.

Kiedy w Mezopotamii powstawała standardowa wersja Eposu o Gilgameszu, w starożytnym Egipcie już zostały spisane na papirusach największe traktaty medyczne, nazwane od imion ich odkrywców Papirus Kahuna, Papirus Edwina Smitha, Papirus Hearsta, Papirus Brugscha ${ }^{8}$ oraz Papirus Ebersa. Prawdopodobnie w jednym z najstarszych zachowanych traktatów medycznych, Papirusie Ebersa $(855,856,3)$, badacze odkryli zapis, po odczytaniu którego stwierdzili, że w okresie, kiedy papirus powstawał ${ }^{9}$, serce było już uznawane za centrum systemu przewodów, przez który dostarczało do innych narządów wodę i pneumę. Zdaniem Jamesa Breasteda, tłumacza pierwszego chirurgicznego traktatu nazwanego Papirusem Smitha, w starożytnej medycynie egipskiej związek między biciem serca a krążeniem obwodowym był konceptualizowany, mimo że sama koncepcja krążenia była nieznana. Przyjmowano istnienie dwóch układów naczyniowych w ludzkim ciele: żyły, które przenoszą produkty trawienia z przewodu pokarmowego do całego ciała, i tętnice, które przenoszą pneumę z płuc do innych narządów. Lewa strona serca była odpowiedzialna za przepływ pneumy z płuc do tętnic reszty ciała ${ }^{10}$. Według tłumacza traktatu spisanego na papirusie, mimo że nie ma w tekście bezpośredniego nawiązania do badania pulsu, tętno kojarzone było z pracą serca, co można wywnioskować na podstawie fragmentu opisu: ,[...] pracę ser-

7 „But he cannot lift his dead, I touch his heart but it does not beat at all” (Myths from Mesopotamia: Creation, The Flood, Gilgamesh, and Others, tł. S. Dalley, Oxford 2000, s. 93).

8 Niektórzy historycy uważają, że ten papirus był wykorzystywany przez Galena. Por. J. Willerson, Egyptian Contributions to Cardiovascular Medicine, „Texas Heart Institute Journal” 23/3 (1996) s. 191-200.

9 Por. J.H. Breasted, The Edwin Smith Surgical Papyrus: published in facsimile and hieroglyphic transliteration with translation and commentary in two volumes, Chicago 1991, s. 34.

10 Por. J.F. Nunn, Ancient Egyptian Medicine, London 1996. 
ca można wyczuć w niektórych miejscach ciała" ${ }^{11}$. Informacja sugerująca ocenę pracy serca przy użyciu palca znajduje się natomiast w Papirusie Ebersa (854): ,[...] dzięki palcom badającego lekarza, którymi [wyczuje] pracę serca $w$ różnych miejscach ciała" 12 . $Z$ dużym prawdopodobieństwem można przyjąć, że teksty te odnoszą się do badania pulsu, jednak czy i jakie to mogło mieć dla medyka egipskiego znaczenie diagnostyczne, do chwili obecnej nie jest wyjaśnione. Być może nowe tłumaczenia papirusów pozwolą na dodatkową interpretację.

Czy zatem w medycznej starożytności Wschodu nie zajmowano się pulsem w zakresie diagnostycznym? $\mathrm{Z}$ dostępnych tekstów wynika, że tętno badano w Chinach już około dwa i pół tysiąca lat temu. Według Elisabeth Hsu, autorki Pulse Diagnosis in Early Chinese Medicine, najwcześniejsze opracowanie chińskiej diagnozy pulsu zawarte zostało w pamiętniku lekarza Chunyu Yi 淳于 意 $\mathrm{z}$ dynastii Han (206 rok przed Chrystusem do 220 po Chrystusie). Na dzieło składa się opis dwudziestu pięciu przypadków medycznych, stanowiąc tym samym dokument o ogromnym znaczeniu dla poznania chińskiej medycyny, oraz biografia wspomnianego lekarza. Zdaniem Elisabeth Hsu jest jednocześnie najstarszym przykładem diagnozowania na podstawie badania pulsu w Chinach. Do tego celu wykorzystywano tzw. pulsacyjną metodę diagnostyczną opartą na dotyku nazwaną badaniem mai 脈 (naczyń, pulsów, kanałów). Prawdopodobnie dzieło zostało ukończone ok. 86 roku przed Chrystusem, czyli przed ostateczną kompilacją Wewnętrznego Kanonu Żóltego Cesarza Huangdi nei jing ${ }^{13}$. Ten najbardziej znany w świecie medycznym traktat chiński był kompilowany w okresie od IV do I wieku przed Chrystusem i łączony jest z mityczną postacią Żółtego Cesarza Huang Di, którego panowanie datuje się na ok. 2600 lat przed Chrystusem ${ }^{14}$. Głównym sposobem diagnozowania w Huángdì Nèijing było badanie fizykalne pulsu tętniczego, na który składają się różne etapy interakcji między Yin (choroba) i Yang (zdrowie). Starożytni chińscy lekarze rozwinęli umiejętności oceny stanu choroby (przyczyny, czasu trwania i rokowania) według czterech głównych odmian rytmów tętna: powierzchownego i głębokiego, wolnego i szybkiego ${ }^{15}$. Badanie przepro-

11 Por. Breasted, The Edwin Smith Surgical Papyrus, s. 34.

12 Breasted, The Edwin Smith Surgical Papyrus, s. 34.

13 Por. E. Hsu, Pulse Diagnosis in Early Chinese Medicine, Oxford 2010, s. 47.

14 Por. E. Kajdański, Chiny: leksykon, Warszawa 2011, s. 130-131.

15 Por. T.N. Huang, The Yellow Emperor's Classic of Internal Medicine, New York 1966. 
wadzano wcześnie rano na nadgarstkach obu rąk, ponieważ uważano, że właśnie wtedy Yin i Yang są w równowadze ${ }^{16}$. Lekarz oceniał częstość tętna na podstawie stosunku tętna do ilości wdechów liczonych w tym samym czasie, przy czym za prawidłowe uważano cztery uderzenia tętna podczas jednego wdechu. Lokalizacja pulsu w różnych częściach obu kończyn górnych przedstawiała stan dwóch różnych narządów ciała ${ }^{17}$.

Według autorów artykułu Past, Present, and Future of the Pulse Examination (脈診 mài zhěn) badanie pulsu (脈 診 mài zhěn) jest unikalnym podejściem diagnostycznym medycyny chińskiej ${ }^{18}$.

Diagnoza tętna była aspektem medycyny chińskiej najbardziej podziwianym w Europie, ponieważ wybrane fragmenty traktatów medycznych stały się dostępne w thumaczeniu od końca XVII wieku. Do dziś [ich] diagnoza tętna spotyka się z fascynacją i niedowierzaniem ${ }^{19}$.

Starożytna medycyna chińska ma wiele cech wspólnych z medycyną ajurwedyjską. Obydwie są traktowane jako komplementarne lub alternatywne. Podstawą dla powstania i rozwoju medycyny ajurwedyjskiej była filozofia życia związana z hinduizmem, a w szczególności z yogą. Hinduski lekarz, alchemik i filozof, Kanada, znany również jako Kashyapa, Uluka, Kananda lub Kanabhuk, żyjący między VII a II wiekiem przed Chrystusem ${ }^{20}$, w swoim dziele medycznym tłumaczonym na język angielski jako Science of Sphygmica opisuje puls w różnych stanach fizjologicznych i patologicznych badanego: „W każdym ciele znajduje się łącznie trzydzieści pięć milionów rurek krwi lub kanałów, takich jak żyły i tętnice [...] Z powodu odmiennej pozycji lub kurmy puls mężczyzny musi być zbadany na prawej ręce i puls kobiety

16 Por. B. Flaws, The Technique of Examining the Pulse. The Secret of Chinese Pulse Diagnosis, Colorado 1995, s. 67.

17 Por. J. Wang - L. Wu, The Doctorine of the Pulse. History of Chinese Medicine; Being a Chronicle of Medical Happenings in China from Ancient Times to the Present Period, New York 1973.

18 Por. Yuh-Ying Lin Wang - Sheng-Hung Wang - Ming-Yie Jan - Wei-Kung Wang, Past, Present, and Future of the Pulse Examination (脈診 mài zhěn), „Journal of Traditional and Complementary Medicine" 2 (2012) s. 164.

19 Yuh-Ying Lin Wang - Sheng-Hung Wang - Ming-Yie Jan - Wei-Kung Wang, Past, Present, and Future of the Pulse Examination, s. 3.

20 Por. M. Banarsidass, Sharma. A Critical Survey of Indian Philosophy, Chandradhar 2000. 
na lewej ręce" 21 . Autor wyróżnił również kilka częstości tętna dla różnych grup wiekowych ${ }^{22}$. W oparciu o jego teorię każdy puls ma trzy etapy, na których każda nieprawidłowość odzwierciedla zaburzenia trzech dosz: bayu/vata (powietrze), pitta (żółć) i kaph/kapha (flegma). Dosze są pochodnymi i przejawem pięciu żywiołów które są odzwierciedleniem właściwości materii: przestrzeni (akaśa) - potencji, powietrza (waju) - ruchu, ognia (agni) - przemiany, wody (dźala) - integralności i zwartością materii oraz ziemi (prithwi) - stabilności. Wszystko, co istnieje, składa się z pięciu żywiołów połączonych ze sobą w różnych proporcjach. Zwykle jeden żywioł dominuje nad pozostałymi. Kombinacje żywiołów tworzą wspomniane wyżej dosze, które tworzą sylwetkę psychofizyczną człowieka. Medyk ajurwedy przed badaniem pulsu ocenia: ,[...] sylwetkę pacjenta, sposób mówienia, stan jego skóry, włosów, języka, gałek ocznych, sposób mówienia i poruszania się, bada też puls" 23 . Wynika z tego, że badanie pulsu w medycynie ajurwedy nie stanowi priorytetu dla postawienia diagnozy, jak to mam miejsce w medycynie chińskiej.

\section{Badania nad pulsem w starożytnej Grecji i Rzymie}

Medycyna grecka dominowała w świecie zachodnim do końca starożytności. Dwa rodzaje medycyny: kapłańsko-religijna z bogiem Asklepiosem i leczeniem świątynnym oraz racjonalna, którą zapoczątkował Hippokrates (460-370 rok przed Chrystusem), stanowiły dwie niewykluczające się alternatywy dla leczenia pacjentów ${ }^{24}$.

Jednym z pierwszych Greków, który zauważył różnice między żyłami a tętnicami, był Alkmeon z Krotony (VI wiek przed Chrystusem), według Diogenesa Leartiosa uczeń Pitagorasa ${ }^{25}$. Mimo że w traktatach przypisy-

21 R.L. Gupta, Science of sphygmica or sage kanád on pulse: an English translation with Sanskrit passages, Indie 1891, s. 5-7.

22 V.G.P. Upadhyay, The Science of Pulse Examination in Ayurveda, Sri Satguru Publication, New Delhi 1997.

23 Upadhyay, The Science of Pulse Examination in Ayurveda, Sri Satguru Publication.

24 Por. S.G. Marketos - E. Poulakou-Rebelakou, Traditional medicine in ancient Greece (coexistence of Asclepian art and Hippocratic medicine), „Przegląd Lekarski” 52/12 (1995) s. 612-614.

25 Por. Diogenes Leartios, Żywoty i poglądy stynnych filozofów, tł. W. Olszewski, Warszawa 1984, s. 508-509. 
wanych Hippokratesowi, jak również w traktatach należących do zbioru Corpus Hippocratcum wspominany jest puls, prawdopodobnie przez ówczesnych medyków nie był jeszcze postrzegany jako badanie stosowane dla oceny stanu zdrowia pacjenta ${ }^{26}$.

Sto lat później Arystoteles (384-322 rok przed Chrystusem), nie zagłębiając się szczegółowo w zagadnienia pulsu, napisał, że życiodajna krew pulsuje w cały ciele, a najlżejszą i najczystszą posiada człowiek: „U wszystkich zwierząt krew pulsuje w żyłach równocześnie w całym ciele. Krew jest jedyną cieczą, która przebywa w całym ciele i trwa w nim zawsze, jak długo ono żyje"27.

Pierwszym lekarzem, którego historia medycyny uznała za prekursora badań nad pulsem, był Praksagoras z Kos (ok. 340 rok przed Chrystusem). Swoją karierę rozpoczął w szkole medycznej na wyspie $\operatorname{Kos}^{28}$, zakończył zaś w Aleksandrii ${ }^{29}$. Mimo że nie zachował się żaden z traktatów Praksagorasa, jego nauka nie została zapomniana. $Z$ tej pracy korzystali inni wielcy medycy starożytności, Galen i Celsus ${ }^{30}$.

Był jednym z najważniejszych reprezentantów szkoły dogmatycznej, mającym znaczące osiągnięcia w polu badań anatomicznych. Jednym z nich było wyróżnienie tętnic od żył wraz z próbą stworzenia przejrzystego obrazu układu krwionośnego, który jakkolwiek błędny, stanowił pierwszy ważny krok na drodze zrozumienia jego istotnych z punktu widzenia procesów życiowych

26 Por. N. Ghasemzadeh - M. Zafari, A Brief Journey into the History of the Arterial Pulse, „Cardiology Research and Practice” 11 (2011) s. 3.

27 Por. Arystoteles, Zoologia, w: Arystoteles, Dzieła wszystkie, t. 3, tł. P. Siwek, Warszawa, 1992, s. 403.

28 Por. H. von Staden, The discovery of the body: human dissection and its cultural contexts in ancient Greece, ,Yale Journal of Biology and Medicine” 65 (1992) s. 223-241.

29 Na początku III wieku przed Chrystusem Ptolemeusz I Soter, diadoch Aleksandra Wielkiego, ustanowił stolicą Egiptu Aleksandrię, która stała się miejscem pobytu wielu znanych filozofów i uznanych lekarzy. Dziedzictwem miasta stała się biblioteka będąca w ówczesnym świecie największym repozytorium zwojów, wśród których znajdowały się dzieła wybitnych filozofów. Byli wśród nich Arystarch, Eratostenes, Callimachos, Euclides, Manethos oraz Eratistratos, uczeń Herophilosa uważanego za jednego z największych lekarzy starożytności, przez wielu uznanego za ojca anatomii i założyciela szkoły lekarskiej w aleksandryjskim Muzejonie. Dzięki Muzejonowi Aleksandria stała się w III wieku przed Chrystusem głównym greckim ośrodkiem naukowym zarówno w dziedzinach humanistycznych, jak i ścisłych.

30 Por. A. Wills, Herophilus, Erasistratus, and the birth of neuroscience, „Lancet” 354 (1999) s. 1719-1720. 
funkcji. Swoje badania oparł o sekcje zwłok zwierząt, aczkolwiek wiele wskazuje na to, że celem ostatecznym była dlań anatomia człowieka ${ }^{31}$.

Mimo popularności i uznania w ówczesnym świecie medycznym nie wszystkie jego teorie były niepodważalne. Jego uczeń, Herofilus (335-255 rok przed Chrystusem), twórca i założyciel szkoły lekarskiej w Muzejonie w Aleksandrii, nie akceptował twierdzenia swojego mistrza, jakoby praca serca nie miała znaczenia dla oceny pulsu ${ }^{32}$. Inne teorie były przez niego aprobowane i podobnie jak Praksagoras uważał, że tętnice zawierają pneumę, podczas gdy żyły - krew ${ }^{33}$. Sugerował również wzajemną zależność między rozszerzaniem tętnic pobierających pneumę z serca $z$ jednoczesnym skurczem tętnic, który przesuwa ją do przodu, powodując tym samym powstanie pulsu tętniczego. Wysnuł pogląd, że przedsionki stanowią część serca, podczas gdy popularna i powszechnie akceptowana była teza Arystotelesa o sercu mającym trzy komory z prawym przedsionkiem stanowiącym tylko rozszerzenie żyły ${ }^{34}$.

Współczesny Herofilusowi Erasistratos (310-250 rok przed Chrystusem), prawdopodobnie jego uczeń, twierdził, że serce i tętnice nie poruszają się jednocześnie. Serce składające się jego zdaniem z dwóch komór uważał za główny narząd ciała.

W komorze lewej znajduje się siedlisko „duchów ożywczych” (pneuma). Owa pneuma pochodzi z wciąganego do płuc powietrza, które przedostaje się do żyły płucnej i do lewej komory. W lewej komorze następuje podział pneumy na ,pneuma zootikon” i ,pneuma psychikon”. Pneuma zootikon rozchodzi się po ciele za pośrednictwem tętnic wolnych od krwi, pobudzając czynności wegetatywne organizmu. Natomiast pneuma psychikon, docierając do opony twardej i przez porowate nerwy, uczestniczy w ruchu i odbiorze czucia $^{35}$.

31 R.W. Gryglewski, Rola czynników kulturowych w kształtowaniu się badań anatomicznych opartych o autopsję ludzkiego ciała, „Kultura i Historia” 29 (2016) s. 57.

32 C.U. Smith, The triune brain in antiquity: Plato, Aristotle, Erasistratus, „Journal of the History of the Neurosciences" 19 (2010) s. 1-14.

33 M. Boylan, Galen: on blood, the pulse, and the arteries, ,Journal of the History of Biology" 40/2 (2007) s. 207-230.

34 R. Van Praagh - S. Van Praagh . Aristotle's ,triventricular” heart and the relevant early history of the cardiovascular system, „CHEST Journal” 84 (1983) s. 462-468.

35 A. Katolo, Koncepcje zdrowia i choroby w starożytnej kulturze klasycznej $i$ w ujęciu biblijnym. Próba porównania, „Studia Gdańskie” 24 (2009) s. 199 
Uważał, że tętnice rozszerzają się wtedy, gdy serce kurczy się i odwrotnie, a ruch tętnic następuje po skurczu mięśnia sercowego. Wyjaśnił również poprawnie rozszerzenie naczyń krwionośnych, ale przy błędnym założeniu ruchu pneumy wzdłuż tętnic. Prawdopodobnie podczas badań nad ludzkimi zwłokami ${ }^{36}$ podobnie jak Herofilus zauważył różnice w grubości ścian tętnic i żył ${ }^{37}$.

Herofilus jako pierwszy porównał pulsowanie naczyń krwionośnych (żył) z rytmem muzycznym i opisał analogię między rytmem muzycznym a rytmem pulsacyjnym. Wykorzystał w tym celu tętnicę noworodka i zdefiniował przedział czasu oraz warunki brzegowe, w których będzie się ona rozszerzać. W ten sposób zdefiniowana jednostka stała się podstawą do pomiaru długości każdego skurczu i dylatacji, a zatem podstawową jednostką, za pomocą której ustalano rytm pulsu ${ }^{38}$. Skonstruował również przenośny zegar wodny służący do badania pulsu i wykorzystywał go do sprawdzenia, czy pacjent ma gorączkę i jak wysoką.

Jednak nie wszyscy akceptowali połączenie rytmu pulsacyjnego z rytmem muzycznym. Pliniusz Starszy (23-79 rok po Chrystusie) w Historii naturalnej twierdził, że koncepcja rytmu Herofilusa jest trudna i niezrozumiała dla większości, wymaga bowiem znajomości muzyki, poezji i medycyny. Jego zdaniem takie połączenie doprowadziło do tego, że lekarze nie wykorzystują odpowiednio wyników badań nad pulsem w celu rozwoju medycyny i diagnostyki chorób ${ }^{39}$.

Kilkadziesiąt lat później, na przełomie I oraz II wieku po Chrystusie Archigenes z Syrii ${ }^{40}$ napisał traktat, w którym opisał puls charakteryzujący się czterema cechami: długością, głębokością, szerokością i prędkością. Zaznaczył, że można je odróżnić delikatnym badaniem dotykowym ${ }^{41}$. Uważał również, że rozszerzenie tętnicy nie musi być równomierne z każdej strony i można wyczuć różnorodne impulsy w zależności od stopnia

36 To właśnie jemu przypisuje się prowadzenie pierwszych regularnych sekcji na ludzkich zwłokach, a nawet wykonanie szeregu wiwisekcji na skazańcach, co jednak trudno dzisiaj jednoznacznie potwierdzić. Zob. H. von Staden, Herophilus the Art of Medicine in Early Alexandria, Cambridge 1989, s. 138. Por. Gryglewski, Rola czynników kulturowych w kształtowaniu siębadań anatomicznych opartych o autopsję ludzkiego ciała, s. 57.

37 Boylan, Galen: on blood, the pulse, and the arteries, s. 227.

38 Por. Staden, Herophilus the Art of Medicine in Early Alexandria.

39 Por. Pliny, Natural History 11, 89, 219, t1. J. Bostock, ed. H.T. Riley, United States 1879.

40 E. Horine, An epitome of ancient pulse lore, „Bulletin of the History of Medicine” 10 (1941) s. 209-249.

41 Staden, Herophilus the Art of Medicine in Early Alexandria. 
rozszerzenia z każdej strony ${ }^{42}$. Prawdopodobnie odkrył również i zdefiniował puls dikrotyczny ${ }^{43}$.

Praca Archigenesa została skomentowana przez żyjącego kilkadziesiąt lat później lekarza gladiatorów w Pergamonie, Galena (129-200 rok po Chrystusie), który po przeniesieniu się do Rzymu w szybkim czasie zyskał uznanie i został lekarzem cesarza Marka Aureliusza. Z Galenowego Komentarza wynika, że większość wniosków Archigenesa była bardziej efektem założonej hipotezy niż faktycznej obserwacji badawcza.

W traktacie De pulsuum differentiis ${ }^{44}$ Galen opisał dwadzieścia siedem przypadków pojedynczego impulsu na podstawie jego wielkości, prędkości i częstotliwości ${ }^{45}$. Podobnie jak Herofilus opracował klasyfikację rytmów tętna w zależności od ich odchylenia od „naturalnego rytmu”. Według niego rytm tętna może być „naturalny”, gdy pacjent jest zdrowy, lub „nienaturalny”, gdy pacjent jest chory. W tym przypadku może być „pararytmiczny” (z najmniejszym odchyleniem), ,heterorytmiczny” (z większym odchyleniem) lub „ekrytmiczny” (z największym odchyleniem $)^{46}$. Sugerował również potrzebę zastosowania teorii rytmu tętna $\mathrm{w}$ pomiarze oddechów, a rytm metryczny, który początkowo był uważany za jeden z aspektów tętna, stał się dzięki jego komentarzom istotną kategorią medyczną i naukową kładącą podwaliny pod późniejsze porównywania tętna, oddychania i rytmu.

42 Horine, An epitome of ancient pulse lore, s. 209-249.

43 Puls dikrotyczny charakteryzuje się dwoma uderzeniami na cykl serca, jednym skurczowym i drugim rozkurczowym. Fizjologicznie fala dikrotyczna jest wynikiem fal odbitych z kończyn dolnych i aorty. Stany związane z małą wydolnością serca i wysokim ogólnoustrojowym oporem naczyniowym mogą powodować puls dikrotyczny.

44 W traktacie De Pulsuum Differentiis Galen kilkakrotnie w tekście wykazał zainteresowanie chrześcijanami, jednak bez bezpośredniego związku z teorią pulsu. Por. Galeni Opera de pvlsibvs Hermanno Crvserio Campensi interprete. Quae in hoc opere continentur, proxima pagina indicabit II 4; III 3, Parisiis 1532. Richard Walzer w Galen on Jews and Christians napisał: „Cieszył się przyjaźnią Marka Aureliusza i był odpowiedzialny za zdrowie młodego Kommodusa, gdy cesarz przebywał z dala od Rzymu i prowadził wojnę niemiecką [...] Ale Galen, jak jest najbardziej prawdopodobne, miał dodatkowo okazję spotykać się z poszczególnymi chrześcijanami na dworze [...] Można więc powiązać jego zainteresowanie myślą chrześcijańską z bardziej przychylnym nastawieniem do chrześcijan, który zdaje się dominować w Rzymie od czasu na krótko przed 180 r.n.e." (R. Walzer, Galen on Jews and Christians, London 1949, s. 9).

45 Por. Por. C.R.S. Harris, Galen's Pulse-Lore. The Heart and the Vascular System in Ancient Greek Medicine, from Alcmaeon to Galen, Oxford 1973, s. 187.

46 Por. P. Michon, The Spread of Rhythm in Life Science and Medicine (1st-2nd century AD) - part 2, „Rhuthmos”, (2017) s. 325. 
Poza Galenem, który pozostawił po sobie sześć traktatów na temat pulsu, zachowały się również traktaty anonimowych lekarzy przypisywane niesłusznie Soranusowi (Pseudo-Soranus), wspomnianemu już Rufusowi z Efezu (Pseudo-Rufus) oraz Galenowi (Pseudo-Galen), które są datowane na koniec I oraz początek II wieku po Chrystusie ${ }^{47}$. Prawdopodobnie

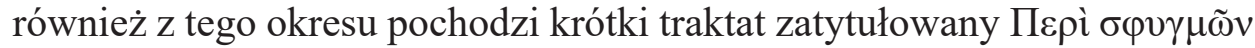
przypisywany rzymskiemu lekarzowi Marcellinusowi.

Traktat ten, który wydaje się być podręcznikiem lub podręcznikiem dydaktycznym dla lekarzy, oferuje zwięzły przegląd starożytnej „sztuki tętna”

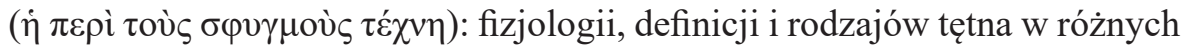
warunkach oraz faktyczny sposób badania pulsu ${ }^{48}$.

Zdaniem Marcellinusa tylko właściwie przeprowadzone badanie palpacyjne umożliwi lekarzowi prawidłowe rozpoznanie subtelnych wartości tętna. Twierdził, że lekarze cieszący się dużym szacunkiem nie wykonują prawidłowo badania palpacyjnego, co prowadziło do błędnej interpretacji znaczenia ruchu, czyli tętna, który wyczuwają. W przeciwieństwie do traktatów innych autorów podkreślił znaczenie bardzo rzadkiego w tamtych czasach szkolenia praktycznego i teoretycznego ${ }^{49}$.

Poza Marcellinusem tylko Pseudo-Soranus uznał za ważne włączenie informacji praktycznych do swojej pracy. Jednak ich poglądy nie w pełni się pokrywały. Marcellinus twierdził bowiem, że puls powinien być badany na obu ramionach czy nadgarstkach pacjenta, podczas gdy Pseudo-Soranus sugerował, że puls należy badać tylko na prawym nadgarstku ${ }^{50}$.

Od III wieku po Chrystusie częścią teorii rytmu tętna stawał się również rytm zdefiniowany muzyką. Zgodnie $\mathrm{z}$ tą definicją tętnice miały poruszać się w rytmie metrycznym lub muzycznym: „W naszym ciele na-

47 Więcej na temat Marcellinusa, datowania jego pracy oraz dyskusji na jego temat w: O. Lewis, Marcellinus' De pulsibus: a Neglected Treatise on the Ancient „,Art of the Pulse”, „Scripta Classica Israelica” 34 (2015) s. 195-214.

48 Lewis, Marcellinus'De pulsibus: a Neglected Treatise on the Ancient „,Art of the Pulse”, s. 196.

49 Por. Lewis, Marcellinus'De pulsibus: a Neglected Treatise on the Ancient „Art of the Pulse”, s. 196.

50 Por. Lewis, Marcellinus' De pulsibus: a Neglected Treatise on the Ancient „Art of the Pulse”, s. 210-211. Faktycznie ramię, na którym powinno się badać puls, powinno być ustalane w każdym przypadku i stosownie do pozycji, w jakiej znajduje się pacjent. 
turalnie byłaby muzyka i poezja i ta muzyka byłaby naturalnie związana z kosmiczną muzyką sfer"s1.

Żyjący w tamtych czasach Censorinus, rzymski pisarz i gramatyk, $\mathrm{w}$ De die natali tematycznie obejmującym różnorodne zagadnienia, $\mathrm{w}$ tym naturalną historię człowieka, muzykę, obrzędy religijne, astronomię, nauczanie greckich filozofów, nawiązując do Herofilusa, napisał, że pulsacje żył odbywają się w rytmach muzycznych ${ }^{52}$. Ponad tysiąc lat później Remigius Autissiodorensis (841-908 rok po Chrystusie), benedyktyński mnich, autor komentarzy do klasycznych greckich i łacińskich dzieł w komentarzu do utworu Martianusa Minneusa Felixa Capelli wyraża uznanie dla Herofilusa za zbadanie rytmu ży $1^{53}$.

\section{Kontynuatorzy w Bizancjum i wczesnej medycynie arabskiej}

Na początku V wieku po Chrystusie, kiedy medycyna w zachodnim Cesarstwie Rzymskim przechodziła kryzys i chyliła się ku upadkowi, we wschodnim Cesarstwie Rzymskim następuje szybki rozwój medycyny bizantyjskiej wykorzystującej wiedzę medyczną zawartą w dziełach Hippokratesa i Galena ${ }^{54}$. Orybazjusz, Aecjusz z Amidy, Aleksander z Tralles i Paweł z Eginy to lekarze tworzący medycynę i wyznaczający jej trendy we wczesnym Bizancjum. Niestety, z zachowanych tekstów nie wynika, że zajmowali się badaniem pulsu w zakresie większym niż wyznaczały to ramy wszechobecnego w medycynie bizantyjskiej ,galenizmu".

Dopiero w pracach arabsko-islamskich lekarzy powraca temat pulsu w zakresie użyteczności jego badania w medycynie. Uważany za jednego z największych lekarzy arabskich średniowiecza Abu Bakr Mohammad Ibn Zakariya al-Razi, znany również pod łacińskim imieniem Rhazes (864-925 rok po Chrystusie), mimo że nie zajmował się teorią pulsu, w swoich pracach nawiązywał do niego, twierdząc, że ,[...] serce ma

51 P. Michon, The Spread of Rhythm in Life Science and Medicine (1st-2nd century $A D)$ - part 3, w: https://rhuthmos.eu/spip.php?article2133 (dostęp: 20.11.2019).

52 „Herophilus autem, artis eiusdem professor, venarum pulsus rhythmis musicis ait moveri”" (Censorinus, De die natali. Liber ad Q. Caerellium 12, 4-5).

53 „Herophilus aegrorum venas rhythmorum collatione pensabat” (Martianus Capella, De nuptiis Philologiae et Mercurii 9, 926, ed. J. Willis, Leipzig 1983, s. 497.

54 Por. R. Porter, The Greatest Benefit to Mankind: A Medical History of Humanity from Antiquity to the Present, London 1997, s. 106-134. 
dwie komory, jedna po lewej i jedna po prawej stronie, a przejścia są od jednej do drugiej ${ }^{55 "}$.

Jednym z pierwszych lekarzy, który zapoczątkował prace nad opisem krążenia małego (płucnego), był Ali Ibn Abbas al-Majusi (930-994 rok po Chrystusie) ${ }^{56}$, a swoimi wnioskami zakwestionował prace Galena na temat anatomii serca. Twierdził również, że tętnice płucne składają się z dwóch warstw włókna: wewnętrznej i zewnętrznej, które umożliwiają ich prace polegające na rozluźnieniu (rozszerzenie) i ściśnięciu (skurcz) tętnic ${ }^{57}$.

Niekwestionowaną i wiodąca postacią w historii medycyny był Ibn Sina (980-1037 rok po Chrystusie), bardziej znany jako Awicenna ${ }^{58}$. Był pionierem wczesnego średniowiecza w badaniu pulsu oraz jego fali i podobnie jak Herofilus porównał rytmy pulsacyjne do rytmów muzycznych. Sugerował, że tętno powinno być mierzone na nadgarstku, który ustanowił najlepszym miejscem dla jego pomiaru ${ }^{59}$ i to właśnie jemu historycy me-

55 A. Gourdon - J.C. Sournia, La médecine médiévale à travers les manuscrits de la Bibliothèque Nationale, Paris 1982, s. 37.

56 Jako pierwszy opisał krążenie płucne lub przepływ krwi w płucach Ibn Al-Nafis (1213-1288), zaprzeczając teorii krążenia płucnego Galena. Por. J.P. Bounhoure, Histoire de la cardiologie: des hommes, des découvertes, des techniques, Toulouse 2004, s. 23.

57 Bounhoure, Histoire de la cardiologie, s. 23.

58 W Traktacie o pulsie (Risolai nabziya) opisał dokładnie rodzaje pulsu. Jednak znacznie więcej informacji na temat pulsu wraz z wykazem dziesięciu rodzajów tętna Awicenna omawia w rozdziałach od czwartego do ósmego traktatu Kanon Medycyny. Sporządzony przez niego wykaz pozwala na szczegółowy opis każdego z nich. Według Awicenny do oceny pulsu stosuje się również dziesięć różnych parametrów, których połączenie w kombinacji dwóch lub więcej daje trzynaście złożonych impulsów. Tętno w jego opinii jest związane z wiekiem i płcią. Puls mężczyzny jest silny, powolny i spokojny, podczas gdy puls kobiety jest słaby i szybki. W okresie dzieciństwa puls jest masywny i bardzo miękki, podczas gdy w okresie młodzieńczym staje się już masywny i szybki, aby w średnim wieku zmienić się w cienki i umiarkowany. Puls osób starszych staje się coraz wolniejszy. Na parametry tętna mogą mieć wpływ różne czynniki, takie jak środowisko, sposób odżywiania, ćwiczenia fizyczne, u kobiet ciąża, sen, sposób wybudzania, ból oraz gorączka. Również różne stany emocjonalne, typu gniew, lęk, smutek i radość mogą zaburzać prawidłowy rytm pulsu. Awicenna kontynuował i przedstawił swoją wersję zapomnianego prawdopodobnie na kilkaset lat diagnozowania chorób na podstawie pulsu. Jego zdaniem tętno chorego człowieka powinno być czynnikiem różnicującym trudne do zdiagnozowania choroby i sam zaproponował pięćdziesiąt rodzajów pulsów występujących w różnych chorobach. Por. M.M. Zarshenas - Z. Abolhassanzadeh - P. Faridi, A. Mohagheghzadeh, Ibn Sina's treaties on pulsology, „Heart Wievs” 46/2 (2011) s. 243-244.

59 Zarshenas - Abolhassanzadeh - Faridi, A. Mohagheghzadeh, Ibn Sina's treaties on pulsology, s. 243-244. 
dycyny przypisują pierwszeństwo w nadgarstkowym badaniu tętna. Był pierwszym lekarzem i filozofem, który zaproponował prawidłowe wyjaśnienie teorii pulsu, poprawiając i uzupełniając tym samym niepodważalną do jego czasów teorię pulsu Galena.

\section{Podsumowanie}

Poza fundamentalnymi pracami Galena dotyczącymi pulsu napisanymi w starożytności i wczesnym średniowieczu istniały prace nie mniej znaczących dla historii medycyny lekarzy, którzy wnieśli wkład w rozwój badań nad tętnem w medycynie starożytnej. Niestety, w większości przypadków ich pisma zaginęły lub uległy zniszczeniu. Dzieła lekarzy okresu hellenistycznego Praksagorasa z Kos, Herofilusa, Eratistratosa i innych znamy tylko dzięki wzmiankom w zachowanych traktatach ich następców. Podobnie jest w przypadku wielu greckich i rzymskich lekarzy w wiekach późniejszych. Ich badania nie tylko nad pulsem nie są rozpowszechniane i nie często są cytowane przez historyków medycyny. Nie możemy również zapominać, że znakomita część medyczno-pisarskiej twórczości Galena to są komentarze do dzieł jego poprzedników, a dzieła jego następców często są kompilacjami jego własnych utworów, czego sami autorzy nie ukrywają, a wręcz akcentują. Prawdopodobnie teorie pulsu Awicenny nie powstałby w takim szerokim zakresie, gdyby twórczość Galena i być może jego poprzedników nie była dla niego inspiracją. Z bardzo krótkiego przeglądu starożytnych prac o pulsie wynika również, że to nie Awicenna zapoczątkował badania pulsu za pomocą nadgarstka, jak jest przyjmowane w historii medycyny, ale były one już powszechnie stosowane w starożytności.

\section{The Theory of the Pulse in Antiquity}

(summary)

Already in antiquity, its importance for the assessment of measurable life parameters was appreciated. However, not all the names of ancient physicians dealing with this subject are known and included in the narrative of the history of medicine. Praxagoras, Herophilus, and Eratistratos are the names of great physicians who contributed significantly to the study of the pulse, and whose works became the basis for further research on the pulse by Galen of his successors. Marcellinus, a physician that was actually "invisible" in the history of medicine until recently, strongly emphasized in his treatise the need to combine 
theory and practice in educating future doctors. In his opinion, practical science allowed to refine the ability to correctly assess and measure the heart rate, which was best felt on the wrist. It is ancient medicine that made pulse measurement the basic tool for diagnosing and determining the patient's health problems. The rhythmic movement of the vessels, involving stretching and contraction of their walls, as a result of the mechanical action of the blood pumped by the heart, provides a lot of important information about the work of our heart, our well-being and emotions.

Keywords: pulse; history of medicine; antiquity

\section{Teoria pulsu w starożytności}

(streszczenie)

Rytmiczny ruch naczyń polegający na rozciąganiu i skurczu ich ścian na skutek mechanicznego działania tłoczonej przez serce krwi dostarcza wiele istotnych informacji o pracy naszego serca, naszym samopoczuciu, emocjach. Już w starożytności doceniano jego znaczenie dla oceny mierzalnych parametrów życiowych. Nie wszystkie jednak imiona starożytnych medyków zajmujących się tą tematyką są znane i uwzględniane w narracji historii medycyny. Praksagoras, Herofilus czy Eratistratos to imiona wielkich lekarzy, którzy w znacznym stopniu przyczynili się do badań nad pulsem, a których dzieła stały się postawą do dalszych badań przez Galena jego następców. Marcellinus, medyk nieznany do niedawna w historii medycyny, mocno akcentował w swoim traktacie konieczność połączenia teorii i praktyki w kształceniu przyszłych lekarzy. Jego zdaniem nauka praktyczna pozwalała dopracować umiejętność prawidłowej oceny i sposobu mierzenia tętna, które najlepiej było wyczuwalne w nadgarstku. To właśnie dzięki zapomnianym starożytnym badaczom, znanym często tylko z przekazów ich kontynuatorów, medycyna starożytna uczyniła mierzenie pulsu podstawowym narzędziem diagnozy pomocnym dla określenia problemów zdrowotnych pacjenta.

Słowa kluczowe: puls; historia medycyny; starożytność

\section{Bibliografia}

\section{Źródla}

Arystoteles, Historia animalium, tł. P. Siwek, Arystoteles, O częściach zwierząt, w: Arystoteles, Dzieła wszystkie, t. 3, Warszawa 1992, s. 616-757.

A. Cornelii Celsi, De medicina libri octo, ed. Ch.V. Daremberg, Lipsiae 1891.

Galeni Opera de pvlsibvs Hermanno Crvserio Campensi interprete. Quae in hoc opere continentur, proxima pagina indicabit, Parisiis 1532.

Diogenes Leartios, Vitae philosophorum, tł. W. Olszewski, Diogenes Laertios, Żywoty i poglądy stynnych filozofów, Warszawa 1984.

Pseudo-Rufus, Synopsis de pulsibus, ed. Daremberg, tł. H. von Staden, Cambridge 1989. 


\section{Opracowania}

Banarsidass M., Sharma. A Critical Survey of Indian Philosophy, Chandradhar 2000.

Boylan M., Galen: on blood, the pulse, and the arteries, „Journal of the History of Biology" 40/2 (2007) s. 207-230.

Breasted J.H., The Edwin Smith Surgical Papyrus: published in facsimile and hieroglyphic transliteration with translation and commentary in two volumes, Chicago 1991.

Dobson J.F., Herophilus of Alexandria, „Proceedings of the Royal Society of Medicine” (1925) s. 9-32.

Ghasemzadeh N. - Zafari A.M., A brief journey into the history of the arterial pulse, „Cardiology Research and Practice” 11 (2011) s. 1-14.

Gryglewski R.W., Rola czynników kulturowych w ksztattowaniu się badań anatomicznych opartych o autopsję ludzkiego ciała, „Kultura i Historia” 29 (2016) s. 55-84.

Gupta R.L., Science of sphygmica or sage kanád on pulse: an English translation with Sanskrit passages, Indie 1891, s. 1-128.

Flaws B., The Technique of Examining the Pulse. The Secret of Chinese Pulse Diagnosis, Colorado 1995.

Furley D.J. - Wilkie J.S., Galen on Respiration and the Arteries, Princeton 1984.

Ganz J., Herophilus and vivisection: A re-appraisal, „General aspects of history and philosophy" (2015) s. 5-12.

Harris C.R.S., Galen's Pulse-Lore. The Heart and the Vascular System in Ancient Greek Medicine, from Alcmaeon to Galen, Oxford 1973.

Henry J., The Edwin Smith Surgical Papyrus, London 1984.

Horine E., An epitome of ancient pulse lore, „Bulletin of the History of Medicine” 10 (1941) s. 209-249.

Huang T.N., The Yellow Emperor's Classic of Internal Medicine, tł. I. Veith, New York 1966.

Kajdański E., Chiny: leksykon, Warszawa 2011.

Katolo A., Koncepcje zdrowia i choroby w starożytnej kulturze klasycznej $i$ w ujęciu biblijnym. Próba porównania, „Studia Gdańskie” 24 (2009) s. 193-209.

Lewis O., Marcellinus' De pulsibus: a Neglected Treatise on the Ancient. Art of the Pulse, „Scripta Classica Israelica” 34 (2015) s. 195-214.

Kovacs M., The Epic of Gilgamesh, Stanford 1989.

Kumaniecki K.F., Historia kultury starożytnej Grecji i Rzymu, Warszawa 1987.

Marketos S.G. - Poulakou-Rebelakou E., Traditional medicine in ancient Greece (coexistence of Asclepian art and Hippocratic medicine), „Przegląd Lekarski” 52/12 (1995) s. 612-614.

Michon P., The Spread of Rhythm in Life Science and Medicine (1st-2nd century AD) - part 2, „Rhuthmos” (2017) s. 321-326.

Myths from Mesopotamia: Creation, The Flood, Gilgamesh, and Others, tł. S. Dalley, Oxford 2000.

Nunn J.F., Ancient Egyptian Medicine, London 1996. 
Praagh R. van - Praagh S. von, Aristotle's ,, triventricular” heart and the relevant early history of the cardiovascular system, „CHEST Journal” 84/4 (1983) s. 462-468.

Staden H. von, The discovery of the body: human dissection and its cultural contexts in ancient Greece, ,Yale Journal of Biology and Medicine” 65 (1992) s. 223-241.

Staden H. von, Herophilus the Art of Medicine in Early Alexandria, Cambridge 1989.

Upadhyay V.G.P., The Science of Pulse Examination in Ayurveda, New Delhi 1997.

Wang J., The Doctorine of the Pulse. History of Chinese Medicine; Being a Chronicle of Medical Happenings in China from Ancient Times, New York 1973.

Walzer R., Galen on Jews and Christians, London 1949.

Wills A., Herophilus, Erasistratus, and the birth of neuroscience, „Lancet” 354 (1999) s. $1719-1720$.

Wiltse L.L. - Pait T.G., Herophilus of Alexandria (325-255 B. C.). The father of anato$m y$, ,Spin” 23 (1998) s. 1904-1914.

Vlachopoulos C. - O'Rourke M., Genesis of the normal and abnormal arterial pulse, „Current Problems in Cardiology” 25/5 (2000) s. 303-367.

Smith C.U., The triune brain in antiquity: Plato, Aristotle, Erasistratus, „Journal of the History of the Neurosciences" 19 (2010) s. 1-14.

Siegel R.E., Galen's System of Physiology and Medicine, New York 1968.

Yuh-Ying Lin Wang - Sheng-Hung Wang - Ming-Yie Jan - Wei-Kung Wang, Past, Present, and Future of the Pulse Examination (脈診 mài zhěn), ,Journal of Traditional and Complementary Medicine" 2/3 (2012) s. 164-185.

Zarshenas M.M. - Abolhassanzadeh Z. - Faridi P. - Mohagheghzadeh A., Sphygmology of Ibn Sina, a Message for Future, „Heart Wievs” 14/3 (2013) s. 155-159. 